\title{
Labor and the State in the Twentieth Century
}

\author{
Doug Reynolds \\ SUNY-Binghamton
}

Among labor historians, a split has emerged between those who believe in a subtle but consistent working-class consciousness and those who believe in sporadic "explosions" of consciousness and struggle. Arguments are complicated by the different roles historians assign to race, age, gender, and ethnicity, as well as by disputes within the histories of technology, business, and economics. One result of these disagreements, it seems, is that historians have taken to addressing each other more often than they speak to a wider audience.

A conference entitled "Labor and the State in the Twentieth Century" was designed to address some specific debates and at the same time to return labor history to those to whom the field should be directed. To this end labor representatives, community activists, and interested academics were invited to the State University of New York at Binghamton on April 4 and 5, 1986 for a fruitful exchange of ideas, ideologies, and history. Funding was provided by the New York State Council on the Humanities and by different State University of New York offices.

The conference opened with talks about "Labor and the State Today" by Nick Salvatore of the New York State School of Labor and Industrial Relations at Cornell University, Bryan Palmer of Queens University in Kingston, Ontario, and Bryan Kane, head organizer of the Broome County (New York) Community-Labor Coalition. Salvatore found few but powerful signs of hope in the post-PATCO era. He pointed to the militancy of Hormel workers in Austin, Minnesota and of Guilford Transportation rail workers in the northeastern United States. Palmer, on the other hand, was less optimistic. Noting the tremendous upsurge of activism (including a threatened general strike) by the Vancouver Solidarity movement as an example, Palmer suggested that activism and consciousness are useless if left in the hands of self-serving union leaders whose bureaucratic power is threatened by rank-and-file militancy.

In the second session, union leaders Larry Cohen (head of organizing for the Communication Workers of America's District One) and Marshall Blake (leader of a dissident local movement in the Service Employees International Union) addressed the problems and necessity of maintaining "respectability" while at the same time winning real, grass-roots reforms. The key, Cohen believes, is for unions to organize communities as well as shop floors. More than ever, community and work-force issues are interrelated. Indicative is the press- 
ing need for significant plant-closing legislation and a national system of health care, areas in which the United States is alone among the world's industrialized countries in its failure. Equally important is the need to alter government involvement in labor relations. This includes, if necessary, the elimination of the National Labor Relations Board, which, Cohen argued, is "an instrument of oppression which provides support for lawyers but nothing but grief for workers."

Both Cohen and Blake stressed the importance of developing strong ties to other groups seeking change, from single-issue organizations, such as the nuclear freeze movement, to broad political movements such as the Rainbow Coalition. The driving forces behind coalition-building efforts are the common enemy shared by labor activists and other proponents of social change and the need to counteract the divide-and-conquer strategy inherent in individualistic laissez-faire Reagan initiatives. Unions must avidly support clean water, peace, and other groups if they are to develop community support for boycotts and strikes.

The issues become less clear where production is tied directly to the state as a primary consumer. Such is the case with the prolific "defense" economy of the Reagan military-industrial complex, an area explored by Nelson Lichtenstein of Catholic University and Tom Joyce of Painters' Union Local 178 in Ithaca, New York. Conversion-the retooling of armament-production facilities for consumer goods production-would have a far-reaching and positive impact on the American economy. Popular enthusiasm for conversion is admittedly weak, as both speakers pointed out, but support may be built through appeals to people's self-interest, especially their desire for peace. Any successful freeze campaign must ultimately be part of a broader call for the uplifting of American workers and their communities.

The experiences of the women's movement lend credence to the importance of building community-labor ties. From comparable worth in the state of Washington and elsewhere to alleged discrimination in the case E.E.O.C. v. Sears, Roebuck and Co., women's rights activists have increasingly struggled to redefine the nature of work in America, though much remains to be done. Ruth Milkman of Queens College, CUNY, used current Bureau of Labor Statistics figures to discuss the needs and potential of working-class women. By the mid-1990s, more than 50 percent of all wage earners will be women, a fact that suggests the need and possibility for radical reorganization of workplace practices. The need for greater organization among women workers is paramount, particularly as the numbers of women involved in the low-wage, service sector work grow. Ellen Gallant, an organizer for Nurses United in upstate New York, pointed out that the problems of low-wage service workers are compounded by the fact that the vast majority of them become dependent on even lower-waged day care and other workers to shoulder the burden of familial obligations. This, Milkman stated, "should be regarded as the nation- 
al crime of the century," as both family and worker suffer while only the employer gains.

The synthesis that emerged from the plenary session and from the conference as a whole offered participants, activists, and academics some useful results. Mediator Melvyn Dubofsky suggested that the American working class tends to have a short historical memory. Despite the severe recession and union busting of the early 1980s, workers helped re-elect Reagan in 1984. Although feelings ran high, collective consciousness was absent in Detroit, Pittsburgh, and other industrial centers devastated by Reagan's policies. It became evident that labor historians, sociologists, and other professionals can broaden individual pockets of resistance if only they could better offer their knowledge to those outside an academic setting. This communication can increase the extent to which organizing redefines the nature of labor and state relations. The conference was meant to be a starting point in this process of expanding communication. As such, it was an unqualified success. 